\title{
Sources of bias, genetic trend and changes in genetic correlation in carcass and ultrasound traits in the icelandic sheep population
}

\author{
Jón H. Eiriksson ANd Ágúst Sigurdsson \\ Agricultural University of Iceland, Hvanneyri, 311 Borgarnes, Iceland \\ E-mail:nonnikotinu@gmail.com; agust@kirkjubaer.is
}

\begin{abstract}
Genetic parameters for carcass conformation, carcass fat, ultrasound eye muscle depth and ultrasound fat depth over eye muscle were estimated with data from Icelandic farms during three periods, 2001-2003, 2006-2008 and 2011-2013. Heritability ranged from 0.30 to 0.42 . Genetic correlation between carcass conformation and carcass fat was $0.41,0.29$ and 0.26 in 2001-2003, 2006-2008 and 2011-2013, respectively.

Breeding values based on carcass scoring records of 5,796,474 lambs in 2000-2013 were estimated with a bivariate model and compared to the results of a multitrait model, including 715,771 ultrasound records. The genetic merit of rams for carcass conformation was underestimated in the bivariate analysis in the cases where many offspring were kept for replacement. Applying the multitrait model reduced this bias and gave more accurate results for both traits.

The genetic trend was -0.05 and 0.08 genetic standard deviations per year for carcass fat and carcass conformation, respectively, in the period 2000-2013.
\end{abstract}

Keywords: Multitrait model, selection response, lamb, carcass quality.

\begin{abstract}
YFIRLIT
Ástcður bjögunar, erfðaframför og breytingar á erfðafylgni fyrir kjötmat og ómmaelingar i islenska sauðfjárstofninum.

Markmið rannsóknarinnar var að kanna hvort kynbótamat fyrir kjötmatseiginleika hjá íslensku sauðfé væri bjagað vegna vals á grundvelli dóma á lifandi lömbum. Einnig að athuga áhrif úrvals á erfðafylgni fitu og gerðar sláturlamba og erfðaframfarir í stofninum. Erfðastuðlar voru metnir með gögnum fyrir árin 2000-2013 frá Bændasamtökum Íslands aðskilið fyrir mismunandi tímabil. Niðurstöður kynbótamats með tvíbreytugreiningu á kjötmatseiginleikum voru bornar saman við kynbótamat einnig keyrt með ómmælinganiðurstöður. Erfðafylgni var metin 0,41 árin 2001-2003 en 0,29 og 0,26 fyrir 2006-2008 og 2011-2013. Kynbótamat fyrir gerð reyndist bjagað hjá hrútum sem mikið er sett á undan í tvíbreytugreiningunni en engin merki svipfarsvals sáust gagnvart fitunni. Erfðaframfarir voru metnar -0,05 staðalfrávik erfða á ári fyrir fitu og 0,08 staðalfrávik erfða á ári fyrir gerð. Fjölbreytu kynbótamat og minnkandi erfðafylgni getur stuðlað að enn meiri ræktunarframförum til framtíðar.
\end{abstract}

\section{INTRODUCTION}

The Icelandic sheep population is rather large with about 475,000 winterfed sheep (Matvælastofnun 2016). Nearly all the sheep farms participate in the recording program of the Farmers Association of Iceland. In recent decades great emphasis has been put on improving carcass quality of lambs in the population. Pioneer work in this field was done 
on the Hestur Research farm (Thorsteinsson 2002). In the beginning, all emphasis was on improved slaughter weight and more muscle, but since 1978 , following market demand, reducing fat has been part of the objective (Thorsteinsson 2002).

Artificial insemination as well as trading with replacement lambs between flocks has created genetic links between flocks around the country and has spread the progress from the Hestur research farm (Thorsteinsson 2002, Jónmundsson et al. 2007). Farmers have also become motivated to improve their stock with their own selection plan.

Since 1998 all carcasses in Icelandic slaughterhouses have been evaluated with the EUROP system for carcass fat (CF) and carcass conformation (CC). CC is graded to five classes, $\mathrm{E}, \mathrm{U}, \mathrm{R}, \mathrm{O}$ and $\mathrm{P}$, from the best to the poorest. There are six CF classes based on measurement of tissue depth over the $12^{\text {th }} \mathrm{rib},<5 \mathrm{~mm},<8 \mathrm{~mm}$, $<11 \mathrm{~mm},<14 \mathrm{~mm},<18 \mathrm{~mm}$ and $>18 \mathrm{~mm}$ giving fat classes $1,2,3,3+, 4$, and 5 , respectively, with $1 \mathrm{~mm}$ deviation allowed based on visible fat on other parts of the carcass (Reglugerð um gæðamat, flokkun og merkingu sláturafurða nr. $882 / 2010$ ). These scores are used for progeny testing and genetic evaluation. Breeding values for $\mathrm{CF}$ and $\mathrm{CC}$ are a major tool in the selection of breeding stock in the population (Örnólfsson et al. 2007).

Ultrasound measures of eye muscle depth (UMD) and fat depth over eye muscle (UFD) over the $3^{\text {rd }}$ lumbar vertebra have been routinely used to select breeding stock and for progeny testing in Iceland since the early 1990's (Thorsteinsson et al. 1994) along with other in vivo scores, e.g. for shoulder and leg conformation of lambs. These measures have high genetic correlation with the carcass scores (Einarsson et al. 2015). Selection of replacements based on these traits is therefore likely to affect genetic analysis for the carcass traits. As a selected group of the lambs is kept for replacement and therefore not measured for carcass traits, there is a risk of bias in the genetic evaluations (Jónmundsson \& Sigurdsson 1999). The correlation with in vivo traits also gives the possibility of correcting the estimates by including them in a multitrait analysis. The ability of multitrait models to account for selection for a correlated trait and therefore correct possible bias is widely assessed in the literature (e.g. Schaeffer 1984).

Sævarsson (1999) estimated a genetic correlation of 0.48 between $\mathrm{CC}$ and $\mathrm{CF}$ in Icelandic sheep, using one year of slaughter house data. Einarsson et al. (2015) estimated a correlation of 0.40 with data from $2007-$ 2008. According to the theory, selection for less fat and more muscle will gradually lead to antagonistic genetic correlation between the two traits and change the possible rate of genetic gain accordingly (Falconer 1989).

Selection for lower fat and more muscle in the carcass on the Hestur research farm showed decreasing fat over ribs and increased eye muscle area (Thorsteinsson 2002). Örnólfsson et al. (2007) reported a genetic trend towards higher CC in 1993-2005 in the recorded Icelandic sheep population as a whole, but not for CF. Rams used for artificial insemination showed a trend towards less fat.

The aim of this study was to analyse the effect of certain probable sources of bias on genetic evaluation for carcass traits in Icelandic sheep and to make an effort to estimate the possible benefit of including ultrasound measurements in the genetic analysis. A further aim was to investigate the rate of genetic progress and to what extent selection has changed the genetic correlation between the measurements of the two types of tissues.

\section{MATERIAL AND METHODS \\ Data}

Data on 7,801,189 lambs born in 2000-2013 from the database of the sheep recording program of the Farmers Association of Iceland were available for the study. Of these 5,796,474 had records for carcass traits, and 715,771 had UFD, UMD and live weights recorded. Ultrasound measures are only available from limited proportion of flocks and usually only part of each flock is measured. Four times more females are measured than male. Which lambs are measured in each flock is up to their owners. 
Common criteria might be minimum weight or ranking based on pedigree or conformation. Pedigree information for 905,923 additional animals born in the years 1950 to 1999 was also available. For all analyses the carcass scoring was transformed to a linear scale, as done in previous studies with Icelandic carcass data (e.g. Einarsson et al. 2015). The linear values of $\mathrm{CC}$ classes were $\mathrm{E}=14, \mathrm{U}=11, \mathrm{R}=8, \mathrm{O}=5$ and $\mathrm{P}=2$. For $\mathrm{CF}$ the values were $1=2,2=5,3=8$, $3+=9,4=11$ and $5=14$.

\section{Genetic parameter estimation}

Genetic parameters were estimated using different subsets of all the data. The use of subsets was mainly to get manageable data to work with for the parameter estimation, but also to shed light on possible changes in variance components through time as selection is expected to have been quite strong. Table 1 shows information on these sets. For each subset the flocks with the largest number of ultrasound measures were included, choosing different size limits to get approximately equally sized datasets. Only ultrasound records of lambs with live weight at time of ultrasound measurement 20 to $65 \mathrm{~kg}$, UMD 17 to $43 \mathrm{~mm}$ and UFD 1.0 to $7.0 \mathrm{~mm}$ were included in the genetic parameter estimation in order to exclude abnormal records. Carcass records where carcass weight was lower than $5 \mathrm{~kg}$ or higher than $35 \mathrm{~kg}$ were excluded, and records of lambs without known sex were also eliminated. Pedigree was traced as far back as possible, starting from animals with recorded traits.
The model used for each trait was:

$$
Y_{i j k}=H Y_{i}+W S_{j}+a_{k}+e_{i j k}
$$

where $Y_{i j k}$ is the phenotypic record of animal $k$, from flock $i$ and weight-sex class $j, H Y$ is the fixed effect of flock-year $i, W S_{j}$ is the fixed effect of weight-sex class $j, a_{k}$ is the random effect of animal $k$ with variance $\sigma^{2}$ and $e_{i j k}$ are random residuals with variance $\sigma^{2}$. Carcass traits were corrected for carcass weight, while ultrasound traits were corrected for live weight. Inbreeding was ignored when building the relationship matrix.

The REML method with the average information algorithm from the DMU package (Madsen \& Jensen 2012) was used for variance component estimation. Convergence criteria were set to $10^{-7}$.

\section{Estimated breeding values}

To study the possible bias in EBV's due to missing information on non-random parts of the population EBV's were calculated based on different subsets of all the data. This was also done to measure how well inclusion of ultrasound measurements compensated for the missing carcass information. Thus, breeding values were estimated with 4 different datasets, including all the data (EBV0), and then omitting information from one (EBV1), two (EBV2) and three (EBV3) of the last years. For each dataset breeding values were estimated for the carcass traits only in a bivariate analysis (cEBVi) and for all the four traits in a multivariate analysis (mEBVi). Data were prepared in the same

Table 1. Criteria for minimum number of ultrasound records for the flock to be included in each subset, number of records and size of the pedigree file in each of the data sets used for genetic parameter estimation.

\begin{tabular}{ccccccc}
\hline Years & Criteria & Flocks & Carcass & Ultrasound fat & $\begin{array}{c}\text { Ultrasound } \\
\text { muscle }\end{array}$ & Pedigree \\
\hline $2000-2013$ & $>3,300$ & 12 & 131,398 & 46,877 & 49,734 & 193,285 \\
$2001-2003$ & $>200$ & 98 & 148,513 & 34,963 & 34,963 & 240,706 \\
$2006-2008$ & $>400$ & 62 & 139,552 & 29,429 & 34,243 & 238,298 \\
$2011-2013$ & $>750$ & 44 & 107,778 & 43,973 & 45,165 & 208,110 \\
\hline
\end{tabular}


manner as for parameter estimation but with a few additional records as limits for ultrasound records to be included were relaxed slightly based on further investigation of individual records. The limits for live weight at the time of ultrasound measurement were 15 to $75 \mathrm{~kg}$, for UMD 13 to $43 \mathrm{~mm}$ and for UFD 0.5 to $8.0 \mathrm{~mm}$. The same model as for parameter estimation was used, except that the relationship matrix included inbreeding. The following pragmatic way was used to form a (co)variance matrix for the EBV calculations: the weighted mean of the estimated variance components was used, with the estimate from all the years weighing half and each of the others $1 / 6$. The resulting covariance matrix was proven positive definite. The mixed models equations were solved with implicit methods and iterations as described by Sigurdsson \& Arnason (1995).

EBVs with different amounts of information for 2074 rams born in 2010 and 2056 rams born in 2011 were compared to mEBV0 which was assumed to be the true breeding value (TBV). Bias of the EBV was computed as the average difference between EBV and TBV. The standard error of prediction (SEP) was also computed and accuracy (ACC) as the Pearson correlation between EBV and TBV. Only rams that had been ultrasound measured as lambs and had at least four offspring measured with ultrasound in the first year were included. Two subsets for each year were studied separately:

- Selling rams (SR), 132 and 121 rams born in 2010 and 2011, respectively, used in flocks known to sell many lambs to other flocks as breeding stock.

- Keeping rams (KR), the 200 rams with the highest proportion of ultrasound measured offspring from the first year of use kept.

\section{Genetic trend}

In order to eliminate the effects of flocks going in and out of the record program, only flocks with data for all the years were included when estimating genetic trends. Linear regression of mEBV0 on birth year was calculated. The trend is also shown graphically as genetic standard deviations with EBV for lambs born in 2000 set as 0 (Figure 1).

\section{RESULTS}

\section{Genetic parameters}

Estimated variance and covariance components (Table 2) are fairly stable across the four datasets. Estimated genetic parameters (Table 3) are precise with standard error of heritability less than 0.01 and from 0.01 to 0.03 for the genetic correlation. Heritability was highest for UMD and CC, from 0.37 to 0.42 in different subsets, but lowest for $\mathrm{CF}$, or 0.30 to 0.34 in

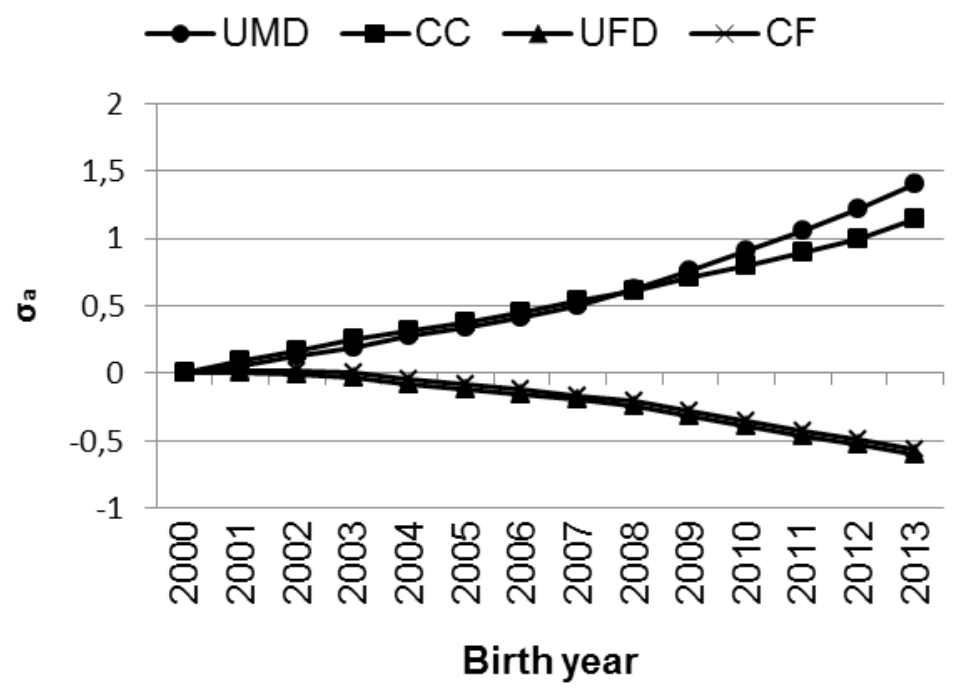

Figure 1. Average breeding values for ultrasound muscle depth (UMD), carcass conformation score (CC), ultrasound fat depth (UFD) and carcass fat score $(\mathrm{CF})$ on year born. 
Table 2. Estimates of additive genetic (a) and residual (e) variance and covariance components for carcass fat (CF), carcass conformation (CC), ultrasound fat depth (UFD) and ultrasound muscle depth (UMD) for each of the four subsets of the data from different periods.

\begin{tabular}{lcccccccc}
\hline & \multicolumn{2}{c}{$2001-2003$} & \multicolumn{2}{c}{$2006-2008$} & \multicolumn{2}{c}{$2011-2013$} & \multicolumn{2}{c}{$2000-2013$} \\
& $\sigma_{\mathrm{a}}^{2}$ & $\sigma_{\mathrm{e}}^{2}$ & $\sigma_{\mathrm{a}}^{2}$ & $\sigma_{\mathrm{e}}^{2}$ & $\sigma_{\mathrm{a}}^{2}$ & $\sigma_{\mathrm{e}}^{2}$ & $\sigma_{\mathrm{a}}^{2}$ & $\sigma_{\mathrm{e}}^{2}$ \\
\hline $\mathrm{CF}$ & 0.593 & 1.169 & 0.533 & 1.174 & 0.494 & 1.088 & 0.519 & 1.191 \\
$\mathrm{CC}$ & 1.003 & 1.395 & 0.877 & 1.502 & 0.905 & 1.397 & 0.995 & 1.414 \\
UFD & 0.270 & 0.500 & 0.273 & 0.429 & 0.232 & 0.363 & 0.222 & 0.408 \\
UMD & 1.589 & 2.337 & 2.163 & 3.111 & 2.273 & 3.190 & 1.893 & 3.269 \\
CF-CC & 0.315 & 0.086 & 0.197 & 0.035 & 0.173 & 0.048 & 0.224 & 0.050 \\
CF-UFD & 0.248 & 0.073 & 0.239 & 0.066 & 0.185 & 0.070 & 0.201 & 0.087 \\
CF-UMD & -0.003 & -0.046 & -0.092 & -0.083 & -0.100 & -0.046 & -0.081 & -0.064 \\
CC-UMF & 0.073 & 0.015 & 0.026 & -0.004 & 0.013 & -0.013 & 0.028 & 0.001 \\
CC-UFD & 0.551 & 0.112 & 0.648 & 0.308 & 0.689 & 0.279 & 0.650 & 0.261 \\
UFD-UMD & 0.000 & 0.011 & -0.025 & -0.065 & -0.059 & -0.059 & -0.021 & -0.028 \\
\hline
\end{tabular}

Table 3. Heritability (diagonal), genetic correlation (below diagonal) and phenotypic correlation (above diagonal) for carcass fat (CF), carcass conformation (CC), ultrasound fat depth (UFD) and ultrasound muscle depth (UMD) for each subset of the data from four different periods. Standard error in brackets.

\begin{tabular}{|c|c|c|c|c|c|}
\hline & & $\mathrm{CF}$ & $\mathrm{CC}$ & UFD & UMD \\
\hline \multirow{4}{*}{$2001-2003$} & $\mathrm{CF}$ & $0.34(0.01)$ & 0.20 & 0.28 & -0.02 \\
\hline & $\mathrm{CC}$ & $0.41(0.01)$ & $0.42(0.01)$ & 0.07 & 0.22 \\
\hline & UFD & $0.62(0.02)$ & $0.14(0.02)$ & $0.35(0.01)$ & 0.01 \\
\hline & UMD & $0.00(0.02)$ & $0.44(0.02)$ & $0.00(0.03)$ & $0.40(0.01)$ \\
\hline \multirow{4}{*}{$2006-2008$} & $\mathrm{CF}$ & $0.31(0.01)$ & 0.12 & 0.28 & -0.06 \\
\hline & $\mathrm{CC}$ & $0.29(0.02)$ & $0.37(0.01)$ & 0.02 & 0.27 \\
\hline & UFD & $0.63(0.02)$ & $0.05(0.03)$ & $0.39(0.02)$ & -0.05 \\
\hline & UMD & $-0.09(0.02)$ & $0.47(0.02)$ & $-0.03(0.03)$ & $0.41(0.02)$ \\
\hline \multirow{4}{*}{ 2011-2013 } & $\mathrm{CF}$ & $0.31(0.01)$ & 0.12 & 0.26 & -0.05 \\
\hline & $\mathrm{CC}$ & $0.26(0.02)$ & $0.39(0.01)$ & 0.00 & 0.27 \\
\hline & UFD & $0.55(0.02)$ & $0.03(0.02)$ & $0.39(0.01)$ & -0.07 \\
\hline & UMD & $-0.09(0.02)$ & $0.48(0.02)$ & $-0.08(0.02)$ & $0.42(0.01)$ \\
\hline \multirow{4}{*}{$2000-2013$} & $\mathrm{CF}$ & $0.30(0.01)$ & 0.13 & 0.28 & -0.05 \\
\hline & $\mathrm{CC}$ & $0.31(0.02)$ & $0.41(0.01)$ & 0.02 & 0.26 \\
\hline & UFD & $0.59(0.02)$ & $0.06(0.02)$ & $0.35(0.01)$ & -0.03 \\
\hline & UMD & $-0.08(0.02)$ & $0.47(0.02)$ & $-0.03(0.02)$ & $0.37(0.01)$ \\
\hline
\end{tabular}




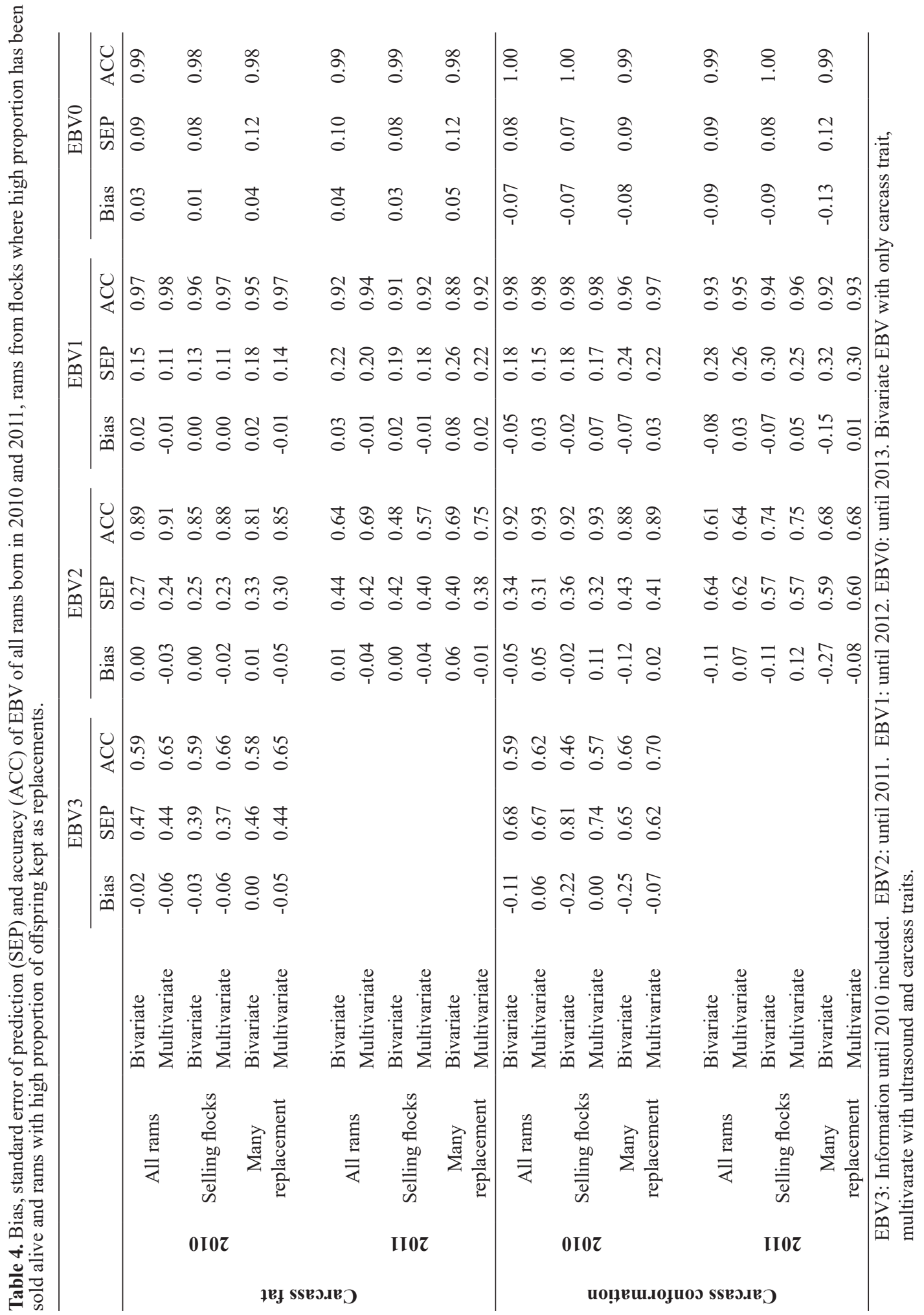


different subsets. Genetic correlation between carcass traits was 0.41 in 2001-2003 and higher than in 2006-2008 and in 2011-2013, where the correlations were 0.29 and 0.26 , respectively. UMD and UFD were not genetically correlated except for slight negative correlation, or -0.08 , in 2011-2013.

\section{Estimated breeding values}

Comparison of carcass trait EBV for selected rams with different amounts of information to the one with most information (Table 4) showed how the estimates improved as the information accumulated. The cEBV3 for rams born in 2010 and cEBV2 for rams born in 2011 were only based on pedigree. The mEBV3 and mEBV2 for the same groups also included the ultrasound measures for the rams themselves, which increased ACC and reduced SEP for CC and CF. Downward bias for CC also decreased, especially in the KR group. In the multivariate analysis, CF was slightly biased downwards. When one year of information on offspring was included all ACC was higher and SEP lower for all the groups. Including ultrasound data had a limited effect on ACC and SEP but reduced bias in the CC EBV for the KR groups.

\section{Genetic trend}

Linear regression of EBV on year of birth gave genetic trends of -0.034 and 0.082 points per year for CF and CC, respectively, in 2000-2013. For UFD and UMD the genetic trend was -0.024 and $0.147 \mathrm{~mm}$ per year respectively in the same period. Lambs born in 2013 had 0.41 points lower EBV for CF than lambs born in 2000. For UFD the difference was $0.30 \mathrm{~mm}$. The CC score was 1.12 higher in 2013 and UMD $1.96 \mathrm{~mm}$ higher than in 2000. Also, the genetic trend in muscularity (CC and UMD) increased over the whole timespan, while the trend towards less fat began in 2003 (Figure 1).

\section{DISCUSSION}

\section{Genetic parameters}

The heritability of CF (Table 3) was in line with other studies for the Icelandic breed, 0.27 (Sævarsson 1999) and 0.31 (Einarsson et al., 2015). Einarsson et al. (2015) found the Icelandic CF score to be genetically the same $\left(r_{\mathrm{g}}=0.99\right)$ as the measure of tissue depth over $12^{\text {th }}$ $\mathrm{rib}$, the tissue depth having higher heritability (0.58). This could explain that heritability for the Icelandic $\mathrm{CF}$ is reported to be higher than published estimates for other breeds in general, (e.g. Conington et al. 1998, Maxa et al. 2007, Safari et al. 2005).

The heritability of CC is generally lower for other breeds (e.g. Conington et al. 1998, Maxa et al. 2007). Previous studies with the Icelandic breed on fixed weight bases have shown the same (Einarsson et al. 2015, Sævarsson 1999).

Estimated genetic correlation between carcass traits conforms with the higher genetic correlation for Icelandic lambs (Einarsson et al. 2015, Sævarsson 1999) than in studies for other breeds (e.g. Conington et al. 1998, Maxa et al. 2007). The change in genetic correlation over time may be explained by the influence of selection and is in line with theory (e.g. Falconer 1989). Sævarson (1999) used commercial data from 1998 and his estimate was higher (0.48). Einarsson et al. (2015) used data from 20072008 and their estimate (0.40) was similar to our estimate for the same time period, which supports this hypothesis. Annual genetic change in all traits is increasing over the timespan (Figure 1), indicating that selection is getting stronger. Thus it is surprising how much drop there is in the genetic correlation between the first and second periods compared to the difference between the second and third. If selection was the only reason for the lowered genetic correlation, more response would be expected later in the study period, but the opposite is true. The difference in the genetic covariance between $\mathrm{CC}$ and $\mathrm{CF}$ in 2001-2003 and 2006-2008 was surprisingly high. The residual covariance was also lower in the latter period (Table 2). Selection should only affect the genetic part, so something else had also changed in this period. One hypothesis is that the scoring practice changed in the slaughter houses, the scoring experts having moved their emphasis from factors of the conformation highly correlated with fat cover to others less correlated. 
Our heritability estimates of UMD and UFD (Table 3) fell within the range of studies for other breeds with fixed weight (e.g. Maximini et al. 2012, Safari et al. 2005). Studies on Icelandic sheep have shown similar or higher heritability (Einarsson et al. 2015, Thorsteinsson \& Eythórsdóttir 1998, Thorsteinsson et al. 1994). The low genetic correlation between UMD and UFD fell within the diverse results for other breeds (e.g. Maxa et al. 2007, Maximini et al. 2012, Safari et al. 2005). Studies on Icelandic sheep have also shown both negative (Thorsteinsson \& Eythórsdóttir 1998, Thorsteinsson et al. 1994) and positive (Einarsson et al. 2015) genetic correlation.

Genetic correlation between muscle and fat traits other than $\mathrm{CC}$ and $\mathrm{CF}$ were hardly significantly different between study periods (Table 3) but all showed trends in the same direction, towards less genetic correlation or more negative genetic correlation in the last period. This trend supports previously noted evidence for selection affecting the relationship between muscle and fat in Icelandic lambs. Change in genetic correlation and no correlation between UMD and UFD suggests that the correlation is not based on strong biological connections. This facilitates the production of lean and muscular lambs.

The method of choosing samples for genetic parameter estimates makes inferences for the whole population difficult, since the flocks used are systematically larger and/or use ultrasound more than the average flock. These flocks are more likely to have resulted from effective selection which can alter the results - giving a stronger effect of selection than is true for the whole population. Also worth noting is that the subsets from different periods do include different flocks and fewer flocks in the later periods, each having more records. The possibility that different flocks in different subsets, rather than change in the parameters with time, caused the difference in parameters between subsets cannot be excluded.

\section{Estimated breeding values}

The fact that no bias of CF EBV based on pedigree was detected indicated that selection based on phenotypes, of chosen breeding rams, was negligible for this trait. However, including ultrasound measures increased the ACC (Table 4). The rams' CC TBV turned out to be higher than their cEBV based only on pedigree information. This suggests they had been selected based on UMD or other in vivo traits correlated to $\mathrm{CC}$. The bias was higher for the KR group, indicating that this group consisted of rams that had higher genetic merit for CC than the rest. Including ultrasound measures in first year EBV reduced this bias and increased ACC.

Rams could be prone to bias in EBV due to selection if the best offspring were kept for replacement. This was not clear for the SR groups but the KR group was underestimated for $\mathrm{CC}$ in the bivariate analysis but not when ultrasound was included. The ACC increased for both carcass traits but no bias was detectable for CF. This fits as there were no signs of phenotypic selection for less fat, as previously noted. Carcass EBV for young rams would benefit from including US by increased ACC for $\mathrm{CC}$ and $\mathrm{CF}$ and by preventing underestimation for $\mathrm{CC}$ when a large proportion of the lambs are kept for replacement. This study only looked at EBV for rams since the selection intensity is much higher there than for ewes. The ewes' EBV would also benefit from multitrait EBV by including their own measurements.

Einarsson et al. (2015) estimated genetic correlation between in vivo leg score given by a scoring expert and $\mathrm{CC}$ to be 0.77 , which was higher than between UMD and CC. Including leg scoring could therefore be even more effective than UMD in improving CC EBV.

\section{Genetic trend}

Lower improvement for fat traits than muscle traits (Figure 1) is in agreement with Örnólfsson et al. (2007) who estimated limited genetic improvement in fat $\mathrm{CF}$ for the first years estimated here but considerable for CC. Over this 13-year period improvement of more than one genetic standard deviation for the muscle traits was observed, while considerable progress 
was also detected for an unfavourably correlated trait, CF. Decreasing genetic correlation between $\mathrm{CC}$ and $\mathrm{CF}$ could facilitate further progress in the future. Lower progress for limiting fat should not come as a surprise since no selection based on phenotypes was detected there, while evidence of successful selection for muscle traits was detected.

We are not aware of studies on correlation of carcass traits with other important traits in the Icelandic breed. Further research is needed to investigate whether the strong selection reported in this paper could have an unfavourable effect on other important traits such as fertility or maternal effect on slaughter weight, which are also part of the breeding goal for Icelandic sheep and selected for to some extent.

\section{CONCLUSIONS}

Large genetic improvement in a relatively short time has been made in the Icelandic sheep population with regards to carcass conformation and fat. The estimated breeding value for carcass conformation is biased for rams when a small proportion of their offspring is slaughtered. This can easily be improved by including ultrasound measures in a multivariate analysis. Selection also reduces unfavourable genetic correlation, giving expectation for more progress in the future.

\section{REFERENCES}

Conington J, Bishop SC. Waterhouse A \& Simm G 1998. A comparison of growth and carcass traits in Scottish Blackface lambs sired by genetically lean or fat rams. Animal Science 67, 299-309.

Einarsson E, Eythórsdóttir E, Smith CR \& Jónmundsson JV 2015. Genetic parameters for lamb carcass traits assessed by video image analysis, EUROP classification and in vivo measurements. Icelandic Agricultural Sciences 28, 3-14.

Falconer DS. 1989. Introduction to Quantitative Genetics, 3rd ed. Longman Scientific \& Technical, Harlow, U.K., 438 p.

Jónmundsson JV \& Sigurdsson Á 1999. Kynbótamatið - kynbótamat hrúta. [Estimation of breeding values - Ram breeding values]. Freyr 95
(10) 37-41. [In Icelandic].

Madsen P \& Jensen J 2012. A Users Guide to DMU: A package to analysing multivariate mixed models. Version 6, release 5.1. University of Aarhus, Research Center Foulum, Denmark, 32 p.

Matvælastofnun 2016. Mcelaborð MAST. [The dashboard of the Icelandic Food and Veterinary Authority] Accessed 10.10.2016 at http://mast.is/ default. aspx?pageid=647aa097-b558-452c-99de8994d03bf7c7. [In Icelandic].

Maxa J, Norberg E, Berg P \& Pedersen J 2007. Genetic parameters for carcass traits and in vivo measured muscle and fat depth in Danish Texel and Shropshire. Acta Agriculturae Scandinavica, Section A 57, 49-54.

http://doi.org/10.1080/09064700701440439

Maximini L, Brown DJ, Baumung R \& FuerstWaltl B 2012. Genetic parameters of ultrasound and computer tomography scan traits in Austrian meat sheep. Livestock Science 146, 168-174.

http://doi.org/10.1016/j.livsci.2012.03.007

Örnólfsson EK, Jónmundsson JV, Thorgeirsson S \& Eythórsdóttir E 2007. Kjötgæði, árangur í ræktun. [Carcass quality - Selection responses]. Rit LbhÍ nr. 14, pp. 63-70. [In Icelandic].

Reglugerð um gæðamat, flokkun og merkingu sláturafurða nr. 882/2010 [Regulation on quality grading, classification and identification of slaughter products]. Sjávarútvegs- og landbúnaðarráðuneytið, Reykjavík. Accessed 20 February 2016 at: http://www.reglugerd.is/ interpro/dkm/WebGuard.nsf/58b439f05a7f412f00 256a07003476bc/8bda2b615f13a1 ef002577e6004 ad8c6?OpenDocument. [In Icelandic].

Safari E, Fogarty NM, \& Gilmour, AR 2005. A review of genetic parameter estimates for wool, growth, meat and reproduction traits in sheep. Livestock Production Science 92, 271-289. http://doi.org/10.1016/j.livprodsci.2004.09.003

Schaeffer LR 1984. Sire and cow evaluation under multiple trait models. Journal of Dairy Science 67, 1567-1580.

Sigurdsson Á \& Árnason, $\mathrm{T}$ 1995. Predicting genetic trend by uni- and multitrait models. Acta Agriculturae Scandinavica, Section A 45, 1-10.

Sævarsson SÓ 1999. Erfðastuðlar við mat á dilkakjöt - samanburður á nýju og eldra kjötmati. [Genetic parameters of lamb carcass classification 
scores - Comparison of new and previous carcass classification]. Unpublished B.Sc. thesis. Búvísindadeild Bændaskólans á Hvanneyri 21 p. [In Icelandic].

Thorsteinsson SS 2002. Rannsóknir og kynbætur sauðfjár fyrir bættu vaxtarlagi og betri kjötgæðum. [Research and breeding work in sheep for improved conformation and carcass quality]. Ráðunautafundur 2002 pp. 149-167. [In Icelandic].

Thorsteinsson SS \& Eythórsdóttir E 1998. Genetic parameters of ultrasonic and carcass cross-sectional measurements and muscle fat weight in Iceland lambs. In Proceedings of the 5th World Congress on Genetics Applied to livestock production $24 \mathrm{pp}$. 149-152.

Thorsteinsson SS, Thorgeirsson S \& Einarsdóttir ÓB 1994. Precision of predicting lean and fat weight from live ultrasonic measurements and genetic parameters of these measurements. In Proceedings of the 5th World Congress on Genetics Applied to livestock production 18 pp. 11-18.

Manuscript received 22 December 2016 Accepted 22 February 2017 